\section{ACCOMMODATION OF SCOTTISH SCIENTIFIC} SOCIETIES.

THE movement for the accommodation of the Scottish scientific societies in the Royal Institution Building, Princes Street, Edinburgh, to which we referred in the issue of December 3,1903 , has advanced a stage. On Tuesday, January 19, Mr. Graham Murray, M.P., the Secretary for Scotland, received a representative deputation consisting of the council of the Royal Society of Edinburgh, and delegates specially appointed by the other societies interested. The deputation was introduced by Sir John Batty Tuke, M.P. Lord Kelvin, Sir John Murray, Sir William Turner, Sir E. Rowand Anderson, Lord Playfair, Mr. Bernard, Lord McLaren, and the Lord Justice Clerk made brief statements on behalf of the more important societies represented, each speaker devoting attention to some particular aspect of the scheme. The concentration of scientific effort, the practical unification of important libraries, which under present conditions could not be utilised to anything like their full extent, the enlarged scope the scheme would give for the encouragement of scientific research, the educative value of such a scientific centre upon the community at large, were all touched upon. It was also pointed out that the movement had its origin in the recent report of the departmental committee on the constitution and functions of the Board of Manufactures, and could not, of course, be realised until the schools of art at present accommodated in the Royal Institution were otherwise provided for. The Secretary for Scotland in his reply expressed his sympathy with the object aimed at, although it was impossible for him to commit himself at present to the furtherance of any' scheme which might naturally follow the acceptance of the departmental committee's report. It must be remembered that there were other interests to be considered, and that it was impossible adequately to provide for all claims without removing from the Royal Institution some of the parties already in possession. It might be possible at a less cost and more efficiency to find accommodation for societies like the Royal Society in another building with a less expensive site. At the same time he felt that this was the fitting time for bringing forward a scheme of the kind advocated, when the whole question must be faced and the present chaotic condition of affairs done away with. Referring to some of the practical details which would have to be taken up in carrying out the scheme, the Secretary for Scotland asked if the societies interested had considered the question of the up-keep of the building, and Sir William Turner replied that that question had been gone into very fully, and that they were prepared to accept much the same conditions as held in regard to Burlington House and the various societies housed there, that is, that they were prepared to act the part of tenants if the Government would do the outside or landlord's repairs. Mr. Graham Murray concluded by saying that he would do his best to impress upon the Government the necessity of dealing adequately and generously with what had long been a clamant want.

C. G. K.

\section{$D R, G E O R G E$ SALMON, F.R.S.}

GEORGE SALMON was born in Dublin on September 25, I819, and having received his school education in Cork, he entered Trinity College, Dublin, and graduated in the year 1838 after a distinguished university career. He was elected to a scholarship in classics in 1837 , and obtained first senior moderatorship at the honour degree examination in mathematics in 1838 . In 1840 he was awarded the Madden's premium, having, in No. 1788, VOL. 69] the opinion of the examiners at the fellowship examination, "best deserved to succeed if another fellowship had been vacant." In the year following he was elected to a fellowship. In due course he became tutor, his duties being to lecture to classes of ordinary students twice a day during term, to assist in examining and to advise and direct his pupils. With a large chamber of pupils, such as Salmon's, this work, though not severe, is liable by its frequent interruption to render it extremely difficult for a tutor to carry out any systematic original work; but Salmon knew the value of time, and with his wonderful power of abstraction he produced most of his forty-one mathematical papers and his four great mathematical treatises during his twenty-five years' service as tutor. In $185^{8}$ he was appointed Donegal lecturer, and taught engineering students the calculus in addition to his tutorial work. In 1859 he proceeded to the degrees of B.D. and D.D., and he published in $186 \mathrm{I}$ his first series of sermons preached in the Chapel of Trinity College.

It was natural that a man of Salmon's originality and versatility should have desired freedom from the irksome duties of a tutorship, and in 1862 he was regarded as the fitting successor to Graves in the chair of mathematics. Preferring, however, the Archbishop King's lectureship in divinity, which fell vacant about the same time, and believing he was certain to be elected to this lectureship, he did not present himself as a candidate for the professorship. An unfortunate mistake and the claims of seniority disappointed him, and it was not until 1866 that election to the regius professorship of divinity relieved him from his long tutorial labours. He was obliged to resign his fellowship, and with it his right to cooption by the board, which would have occurred in 1876 .

This is not the place to speak of his work as professor of divinity, of his treatises on theological subjects, of the splendid services he rendered the Church of Ireland during the years following the disestablishment in the revision of the Prayer-book and in matters of finance. Suffice it to say that Salmon's powers seemed to increase with his years, that his capacity for hard work remained intact almost to the end of his life, until, in his latest written words, " my chariot wheels are now running so heavily that you need not be surprised to hear at any time that they have ceased to move at all." 1

In 1888 , on the death of Jellett, Salmon was admitted provost of Trinity College by Letters Patent. He was then in his sixty-ninth year, and he held the office longer than any provost since the Right Hon. Hely Hutchinson, who died in 1794. It was no light task to which he was called. The governing body of the University of Dublin consists of the provost and the seven senior fellows. The provost is appointed by the Crown. The senior fellows attain their position by virtue of seniority, the sole condition having been their election to a junior fellowship on the results of an examination. This board transacts practically all the business of the university, Its members hold the offices of vice-provost, registrar, bursar, senior lecturer, senior dean, catechist, auditor and senior proctor. In addition it not unfrequently happens that a member of the board is librarian, or that he takes part in the examination for fellowship or in some other important examination. There is nothing to correspond to the Cambridge syndicates unless it be the medical school committee or the academic council, and of the former a member of the board is the chairman, while at least three senior fellows and the provost have belonged to the later since its inception in 1874 , the provost being the ex officio chairman. From letter to the Bishop of Chester dated January 12. 
Indeed, Dr. Salmon had no small share in the origination of the academic council-" to cooperate (with the Board) and have a share in the regulation of the Studies, Lectures, and Examinations .... and in the appointment and election of Professors," but during his masterful tenure of the provostship the power of the council was not of importance. Enough has been said to show the difficulty of Dr. Salmon's office as the head of a responsible board overloaded with duties of the most multifarious kind-a board composed of eight men whose united ages at one time approached if they did not exceed the magnificent total of five hundred and eighty years.

However, Salmon was not an old man at seventy, nor, indeed, at eighty, nor did he appear so at eightyfour to anyone who had the good fortune to enjoy at his most hospitable table the delightful flow of his quaint and simple humour. No doubt he did in his later years grow weary of prolonged controversy, and he was willing to put things off with " It will do very well for my time," or he would use his inimitable powers of ridicule or employ the most fantastic and ingenious arguments to crush any proposal that had not his approval. It might have been otherwise had his duties been less laborious, had he not felt constrained to rule the board with a rod of iron, had he, in fact, more time to consider matters which did not claim his immediate attention, yet perhaps he did not fully realise the enormous changes that had taken place in Trinity College during his connection with it - changes due to the growth of knowledge and to the varied conditions of the tenure of fellowship. Since Dr. Salmon obtained fellowship the number of professorships and lectureships has been just doubled. When he entered the college the celibacy statute was in force, and with few exceptions fellows were obliged to take orders. Rich livings and church preferment were to be had. It was possible even for a professor of astronomy to step into a bishopric. Many of the professorships then held by fellows or by ex-fellows are held by fellows no longer. A new and most important body of men has come into existence-the nonfellow professors-men hardly thought of in the days when all power and all authority was vested in the provost and the seven senior fellows. The senior fellows are not. what they were just before Salmon's time. The allurements of matrimony or the seductions of great ecclesiastical positions used to produce a rapid flux, and a senior fellow was generally coopted in the prime of life-not as now the survivor of a set of men whose constitutions have been most thoroughly tested by the rigours of an appalling examination.

Though Salmon was one of the first to experience these changes, they did not appear to him to warrant any corresponding adjustment in college affairs, and some deplore his inaction, yet Trinity College must be ever grateful to her late provost for the noble conservatism with which he defended her independence. He claimed to be the Ordinary of the college chapel, and would not admit the jurisdiction of the Archbishop of Dublin. He took a leading part in the provisions relating to the position of the divinity school, which is absolutely free from clerical domination, its professors being elected by the board on their merits and on their merits alone. Moreover, it must be remembered that the board is now being recruited from fellows only three of whom have taken orders out of the thirty-five elected since the obligation to take orders was repealed; that there is absolutely no religious test for fellowship candidates, so that it is theoretically possible that a board exclusively composed of Mohammedans may at some time be called upon to elect the professors in divinity. He was willing to NO. 1788 , vOI. 69] afford Roman Catholics every facility for religious exercises within the walls of Trinity College, but he would suffer no clerical interference, whether from the Church of Ireland or the Church of Rome. Indeed, those who know anything of Trinity College can detect little of the "Protestant atmosphere" which its opponents say is so oppressive there, though there may be an " anti-clerical atmosphere," if we take the phrase to mean that clerical interference will not be tolerated in the teaching of divinity, science or letters.

Those who had the privilege of knowing Salmon will think of him as a man-not as the great mathematician, the great theologian or the great head of affairs. As a man he was superb-the kindest of friends, the keenest and most subtle of opponents, the most charming and delightful of companions, the best of men. His figure was well known in Dublin-nearly every afternoon he might be seen wandering through the streets; he was a great lover of music, a great chess-player, an omnivorous reader of novels. For many years he was greatly attracted by the theory of numbers ${ }^{1}$ - he said it almost amounted to a disease with him, and he was often seen avoiding the tedium of some meeting by scribbling on his scraps of paper in his search for primes and for periods of recurring decimals. Yet he took the widest interest in ordinary matters. Many Dubliners will recollect their astonishment at seeing the venerable provost. less than a year ago leaving Kingstown on an exceedingly rough day in a small boat to visit the Channel Fleet, which lay at some considerable distance outside the harbour. Many a time he has surprised his friends by writing to them from some remote Swiss valley inaccessible to many a far younger man.

Salmon's first paper was published in 1844 , "On the Properties of Surfaces of the Second Degree which Correspond to the Theorems of Pascal and Brianchon on Conic Sections" (Phil. Mag., xxiv.); his last mathematical paper was "On Periods in the Reciprocals of Primes" (Messenger of Mathematics, 1873, pp. 49-5I). The majority of his papers have reference to numerical characteristics relating to curves and surfaces, and many of these results are summarised in the great chapter "on the order of restricted systems of equations" in his "Modern Higher Algebra." It would be most unfair to Salmon to judge of his contributions to mathematics by his papers alone. He had a great dislike to the physical trouble of writing; he modestly communicated his discoveries to friends or reserved them for incorporation in his books, so that it is a matter of extreme difficulty to say how much is his. Apart from his discovery of new facts, the methods employed in his books must have been of tremendous service in promoting the advance of mathematics. His style was characterised by a complete absence of pedantry and by profound common sense. By a few words, by some geometrical illustration, he dispensed with pages of troublesome analysis. At times the great condensation of his diction may conceal from the casual student the width and the depth of his conclusions, but on referring to an original memoir from which he quotes one is amazed to find that every essential point is reproduced, and that frequently some brilliant addition has been made and left unclaimed by him. It must not be supposed that Salmon shared the characteristic attributed to MacCullagh of shirking analysis and trusting to his great geometrical insight. On the contrary, he seemed to revel in analysis so tedious and so intricate that it would be distasteful to most mathematicians. $\mathrm{He}$ says," "By means of the differential equation I calcu-

1 Having nearly completed a book on this subject, be burned it for some unknown reason.

2 "Treatise on Modern Higher Algebra," art. 260. 
lated the invariant $\mathrm{E}$. Its value was given at length in the second edition, where it occupied thirteen pages, but I have not thought it worth while to reprint so long a formula." Yet to the volume which contained this elaborate investigation and many others involving equal skill and almost equal labour he prefixed the words :--"To A. Cayley, Esq., and J. J. Sylvester, Esq., I beg to inscribe this attempt to render some of their discoveries better known, in acknowledgment of the obligations I am under, not only to their published writings but also to their instructive correspondence."

Questions of priority must be left to some more learned pen, and to a writer who has less reason to revere Salmon and to respect his reticence. The value of his work is shown by the number of the editions and of the translations of his treatises, and by the honours he received from every quarter. "To a friend who might question him about his honours he would say, "You will find all about them in that drawer." He received them with humility, though he well knew he was worthy of them.

\section{DR. W. FRANCIS.}

$\mathrm{D}^{\mathrm{R}}$ . WILLIAM FRANCIS, whose death we recorded last week, was born in London in February, I8I7. After his school-time, spent partly at University College School, but chiefly in France and Germany, at St. Omer, Cravelt, and Gera, he studied for a short time at University College, London (then known as the University of London), whence he proceeded to the University of Berlin and subsequently to Giessen, where Liebig was then at the height of his scientific activity. Here he took the degree of Doctor of Philosophy in 1842 . His long residence abroad, supplemented by frequent subsequent journeys, many of them on foot, gave him an accurate knowledge of French and German, and enabled him to become personally acquainted with a very large number of the leading men of science on the Continent.

In 1842 he established the Chemical Gazette, which he continued to edit until December, I 859 , when it: was merged in the Chemical News. By this publication and by the translations and abstracts he contributed for many years to the Philosophical Magazine, he did valuable service in making known the work of foreign chemists to their English colleagues. Among other work of the same kind were translations of important foreign papers, including Ohm's "Die gálvanische Kette mathematisch bearbeitet " and Helmholtz's celebrated paper, "Die Erhaltung der Kraft," for Taylor's "Scientific Memoirs:" From I85 I until his death he was one of the editors of the Philosophical Magazine and of the Annals and Magazine of Natural History from I859. His wide acquaintance with various branches of science, as well as with leading scientific men at home and abroad, made him well fitted for these functions, and the sound judgment with which he discharged them is generally recognised.

Dr. Francis was one of the original members, probably the last survivor of them, of the Chemical Society, having been elected an Associate in $184 \mathrm{I}$ and a Fellow shortly afterwards. He was elected a Fellow of the Linnean Society in 1844 . He was also a Fellow of the Royal Astronomical Society and an original member of the Physical Society. For the greater part of his life Dr. Francis was actively engaged in business as a partner, since $185^{2}$, in the well-known firm of Taylor and Francis, successors of Richard and John E. Taylor, printers and publishers.

He died at his residence, the Manor House, Richmond, on January 18.

$$
\text { Nก. } 1788 \text {, vOL. 6o] }
$$

\section{NOTES}

A provisional committee has been formed with the object of commemorating the scientific work of the late Prof. A. Cornu by means of a medal struck for that purpose. The committee includes more than fifty members of the Institute of France; and the secretary is M. E. A. Martel, 8 Rue Me'nars, Paris.

THe King, accompanied by the Queen, opened Parliament in state on Tuesday. In the King's speech reference was made to the insufficiency of the supply of the raw material upon which the cotton industry of this country depends, and the hope was expressed that the efforts which are being made to increase the area under cultivation in various parts of the Empire will be attended with success. Among the measures to be introduced is a Bill to amend the laws relating to education in Scotland.

A Laffan message from Rome states that the Academy of Sciences at Turin has divided the Ballauri prize of $1200 l$. between Signor Marconi and Prof. Grassi, of Rome, and has awarded the Brasso prize of $35 \mathrm{ol}$. to the Duke of the Abruzzi.

DR. D. H. Scott, F.R.S., has been elected president of the Royal Microscopical Society for the ensuing year.

The Daily Chronicle announces the death of Mr. W. G. McMillan, secretary to the Institution of Electrical Engineers.

THE petition of the Linnean Society of London praying for the grant of a supplemental charter has been referred to a committee of the Lords of the Privy Council, and is down for consideration by their lordships on March 1 .

A petition in support of the Bill for the adoption of the metric weights and measures, which will be introduced in the House of Lords by Lord Belhaven and seconded by Lord Kelvin, is being extensively signed throughout the kingdom.

Prof. Henri Cordier, of the School of Modern Oriental Languages at Paris, has been appointed president for 1904 of the Geographical Society of Paris.

THE thirty-first annual dinner of the old students of the Royal School of Mines will be held on Friday, February 26, at the Hotel Cecil. The chair will be taken by Mr. A. G. Salamon. Tickets may be obtained from $\mathrm{Mr}$. David A. Louis, 77 Shirland Gardens, London, W.

At the annual meeting of the Psychical Research Society held on January 29, it was announced that the fund intended to endow a research scholarship had reached 6ig5l., but a minimum of $8000 l$. is needed. Sir Oliver Lodge, the retiring president; introduced the new president, Prof. W. F. Barrett, who delivered his presidential address.

IT is proposed to hold a horticultural and gardening exhibition in the month of June next under the auspices of the Royal Botanic Society in the new exhibition grounds of the society, situated in the centre of the Botanic Gardens in Regent's Park. The proposed scheme embraces horticulture, forestry, botany, educational methods, nature-study, and a special section for colonial produce. In addition to the exhibition, lectures and conferences are in course of arrangament.

Grants in aid of research have recently been made from the Rumford fund of the American Academy of. Arts and Sciences as follows :- to Prof. E. W. Morley, for his research on the nature and effects of ether drift, Iool.; to Prof. Carl Barus, for his research on the study by an 